УДК 338.48

\title{
ЛОКАЛЬНІ БРЕНДИ ТА МЕХАНІЗМ \\ ГЕОГРАФІЧНИХ ЗАЗНАЧЕНЬ ХАРЧОВИХ ПРОДУКТІВ В СТРАТЕГІЇ РОЗВИТКУ ВІТЧИЗНЯНОГО ТУРИСТИЧНОГО ПІДПРИЕМНИЦТВА
}

\author{
LOCAL BRANDS AND THE MECHANISM \\ OF GEOGRAPHICAL INDICATIONS OF FOODS \\ IN A STRATEGY OF THE DEVELOPMENT \\ OF DOMESTIC TOURISM ENTERPRENEURSHIP
}

\author{
Захарчин Роман Миронович \\ кандидат економічних наук, доцент, \\ Львівський інститут економіки і туризму \\ ORCID: https://orcid.org/0000-0003-0003-7287 \\ Zakharchyn Roman \\ Lviv Institute of Economics and Tourism
}

\begin{abstract}
Враховуючи сучасні тренди харчування, вимоги до послуг в гастрономічному туризмі, в статті розглядається механізм географрічних зазначень продуктів як потенціал інноваційного розвитку туристичної індустрії в регіонах країни. Географрічні зазначення харчових продуктів, завдяки їх оригінальності, унікальним властивостям, ознакам автентичності та приналежності до культурно-історичної спадщини, облаштування побуту окремих місцевостей, територій, етносів спроможні не тільки захистити «авторство», але й привабити споживачів, туристів, стимулювати розвиток окремих територій в цілому.Висвітлюються переваги локальних вітчизняних брендів продуктів, вирощування та реалізації місцевої їжі. Акцентовано увагу на необхідності активізувати процеси створення національних продуктів із статусом географрічних зазначень, їх маркетинговому супроводі, а також організацію еногастрономічних маршрутів з метою формування привабливого іміджу регіонів та їх туристичного потенціалу.
\end{abstract}

Ключові слова:тренди харчування,гастрономічний туризм, географрічні зазначення продуктів, локальні бренди, еногастрономічні маршрути, імідж регіонів.

\begin{abstract}
Учитывая современные тренды питания, требования к услугам в гастрономическом туризме, в статье рассматривается механизм географических указаний продуктов как потенциал инновационного развития туристической индустрии в регионах страны. Географрические указания пищевых продуктов, благодаря их оригинальности, уникальным свойствам, признакам подлинности и принадлежности к культурно-историческому наследию, обустройству быта отдельных местностей, территорий, этносов способны не только защитить «авторство», но и привлечь потребителей, туристов и стимулировать развитие отдельных территорий в целом. Освещаются преимущества локальных отечественных брендов продуктов, выращивание и реализация местной пищи. Акцентировано внимание на необходимости активизировать процессы создания национальных продуктов со статусом геограсических указаний, их маркетинговом сопровождении, а также организацию эногастрономического маршрутов с целью формирования привлекательного имиджа регионов
\end{abstract} и их туристического потенциала.

Ключевые слова: тренды питания, гастрономический туризм, географические указания продуктов, локальные бренды, эногастрономического маршруты, имидж регионов.

Gastronomic tourism is distinguished as one of the types of tourism industry, what allows to become acquainted with culinary traditions of various cuisines of the world which contain some specificities of the raw materials used, the technology of production, some methods of serving and consumption. Moreover, gastronomic tourism provides the opportunity to learn deeply about the concrete country, its regions, some local features of which have an impact on the culture and the traditions of consumption. Among the other modern trends of production and consumption of food, the enogastronomical roots are starting to gain interest. The article reviews the opportunities of the impact 
and the practical use of this experience on the operation of domestic tourism businesses. The utilization of protected geographical indicationshas found its effective use in world countries which consider this mechanism being an efficient way to protect national products, brands and manufacturers. Geographical indications, as which can also be seen local food, thanks to their creativity, unique characteristics, the signs of authenticity and belonging to cultural-historical inheritance, the lifestyle of individual regions, areas, ethnicities are capable not only of protection of "the authorship", but also attraction of consumers, tourists, stimulation of the development of individual areas as a whole. Taking into account the existing world experience as well as the trends in food industry and the requirements of modern consumers regarding the services in tourism industry, the article illustrates the organization of enogastronomical routes and the mechanism of geographical indicationsof the products as a capability of innovative development and increasing the competitiveness of domestic tourism industry in country's regions. There are proposed some ways to use the advantages of cultivation and realization of local foods both for local consumers and tourists. The attention is paid to the importance of activization of the processes of the creation of the national products with the status as geographical indications, their modern marketing accompaniment and positioning in order to form the attractive image of the regions, attention to their historical inheritance and modern accomplishments.

Keywords: gastronomic tourism, food trends, local brands, enogastronomical routes, geographical indications, region image.

Постановка проблеми. Інноваційні фрорми ведення туристичного бізнесувимагають освоєння нових сегментів туристичного ринку, нових туристично-рекреаційних територій, залучення до туристичної індустрії нових видів ресурсів. Реалізуючи основну мету в стратегії розвитку вітчизняного туризму, фрахівці ставлять перед собою завдання створювати продукт, який спроможний задовольнити сучасні туристичні запити споживачів. Ці завдання покликані носити комплексний характер і бути спрямованими водночас на захист соціальноекономічних інтересів місцевих громад, на збереження стабільного розвитку території, на популяризацію історико-культурної спадщини та побутових звичаїв. Фахівці, які прагнуть бути лідерами на ринку гастрономічного туризму, популярність якого має хорошу динаміку зростання, повинні враховувати сучасні світові тренди у сорері харчування, харчових продуктів, які становлять його основу

Враховуючи зростаюче зацікавлення у споживачів, туристів продуктами місцевого виробництва з унікальними етнічними ознаками, а також інтеграцію України до європейських вимог щодо захисту національних продуктів через механізм геограсрічних зазначень, практику еногастрономічних маршрутів, як потенціалу просування вітчизняних товарних брендів, постає нагальною потребою досліджувати, аналізувати та запроваджувати у практику туристичного бізнесу цей досвід.

Аналіз останніх досліджень і публікацій. Аспекти розвитку гастрономічного туризму мають місце в дослідженнях таких вітчизняних та закордонних вчених як Антоненко В., Божук Т., Борисюк О., Корнілова В., Корнілова Н., Стельмах О., Мітчелл Р., Холл К. та ін. Проблематика фрормування трендів на світовому ринку харчування та в туризмі відо- бражена у працях вчених Крикавського Л., Куліш І., Зиновенко А., Шматко Н. У працях Т. Ткаченко, С. Мельниченко, Кифяк В. [8] розглядаються особливості розвитку туристичних підприємств у сучасних економічних умовах розвитку регіонів України. Попри значну увагу науковців, практиків щодо інноваційних аспектів розвитку туристичної галузі в Україні, до використання сучасних трендів для підвищення економічної ефективності вітчизняного туризму та розвою окремих територій, пошуку шляхів апробації світового досвіду та інплантації закордонних стандартів такий чинник, як механізм геограсрічних зазначень харчової продукції як потенціал підвищення конкурентоспроможності національних товарів і привабливості туристичної галузі практично залишається поза увагою.

Формулювання цілей статті. В контексті пошуку інноваційних факторів впливу на стратегію розвитку туристичної індустрії в Україні метою дослідження визначено розкрити потенціал сучасних світових трендів харчування, можливості їх ефрективної апробації в організації вітчизняного гастрономічного туризму; проаналізувати доцільні шляхи використання механізму геограсрічних зазначень продуктів та проведення еногастрономічних турів як чинників орормування українських локальних брендів харчової продукції, підвищення конкурентноспроможності вітчизняної туристичної індустрії, а також соціально-економічного розвитку регіонів.

Виклад основного матеріалу дослідження. Географрічні зазначення в якості яких можуть розглядатися також і харчові продукти, завдяки їх оригінальності, унікальним властивостям, ознакам автентичності та приналежності до культурно-історичної спадщини, облаштування побуту окремих місцевостей, 
територій, етносів спроможні не тільки захистити «авторство», але й привабити споживачів, туристів, стимулювати розвиток окремих територій в цілому.

Ці можливості необхідно реалізовувати у ссрері обслуговування, зокрема туризмі, торгівлі, ресторанному господарстві, сорері гостинності.

Створення нового туристичного продукту пов'язується 3 освоєнням нових сегментів туристичного ринку, нових туристично-рекреаційних територій, залученням до туристичного ринку нових видів ресурсів [1].

Міжнародний досвід засвідчує, що практика фрормування національних, територіальних, локальних товарних брендів відіграє важливу роль у розвитку сорери послуг, іiї ключових галузей в кожній країні, кожній місцевості. Україна та її регіони володіють широким спектром природних туристично-рекреаційних ресурсів, мають багату і різноманітну культуру і традиції, історію та історико-культурну спадщину, великий потенціал духовного розвитку, культурного збагачення і оздоровлення [9, с. 81].

Сьогодні створюються сприятливі умови для розвитку цих процесів в Україні. Так у вересні 2017 було створено проект $€$ С «Підтримка розвитку системи геограсрічних зазначень», який діє спільно з Міністерством аграрної політики та продовольства України, Міністерством економічного розвитку України, бізнес-асоціаціями та асоціаціями споживачів. Цей проект підсилює наші зобов'язання в рамках асоціації з ЄС не використовувати європейські геограсрічні зазначення та реєструвати власні. 3 метою забезпечення виконання Угоди про асоціацію між Україною та $€ C$ Кабінет Міністрів України постановою від 25.10.2017 року № 1106 затвердив План заходів з виконання Угоди про асоціацію між Україною, з однієї сторони, та Європейським Союзом, Європейським співтовариством 3 атомної енергії і їхніми державами-членами, з іншої сторони. Заходи щодо забезпечення охорони геограсрічних зазначень передбачені п.п. 114-120, 139-155 цього Плану [2, с. 55]. 31 січня 2020 року набув чинності закон України «Про правову охорону геограсрічних зазначень». Він $€$ новою редакцією колишнього закону «Про охорону прав на зазначення походження товарів», гармонізованою із законодавством Європейського Союзу.

Статус захищених географрічних зазначень традиційно використовують країни Європейського союзу. Він передбачає, що окремі найменування, бренди товарів пов'язуються 3 місцевостями, де вони виготовляються, а це зумовлює стабільні властивості та надає гарантії якості, спричинені характерними для місцевості природньо-кліматичними умовами, традиційним досвідом, чи людським фрактором. Тож створення належної правової охорони геограсрічних зазначень на території України сприятиме посиленню зацікавленості національних виробників у підтримці високої якості та збереженню особливих властивостей вироблених ними товарів і підвищенню конкурентоспроможності вітчизняної продукції на європейському ринку [2, с. 51].

3 метою ефрективного використання зареєстрованих геограсрічних зазначень, слід активно просувати цю продукцію, маркуючи ії̈ відповідним чином, інформуючи споживачів про характеристики продукції та об'єктивно рекламуючи. В цьому важлива роль належить вітчизняним підприємцям, які зобов'язані уміло використати фрункції геограсрічних зазначень, а конкретно - інфрормаційну, «яка полягає в тому, що географрічне зазначення містить змістовну інфрормацію, яка надає достовірні відомості про місце виробництва, виробника, продавця, підприємця, про якісні характеристики товару, його специфріку. Інсрормація, яку містить зазначення, сприяє зростанню популярності товару, що впливає на прибуток виробника». А також - рекламну фрункцію, яка «безпосередньо впливає на просування товару на ринку. Рекламоздатне географрічне зазначення має бути довговживаним, використовуватися протягом тривалого часу для позначення товару 3 особливими властивостями та якостями [3, с. 160].

Суб'єкти господарювання, які прагнуть домінувати на ринку, прогнозуючи конкурентну стратегію розвитку, однозначно пов'язують іiі як 3 відповідністю актуальним трендам, так і активними діями щодо їх фоормування. Неприпустимо стояти осторонь, а навпаки веління часу перед туризмом - бути в авангарді цих транссрормаційних змін у потребах споживача і у повній готовності підтримувати і розвивати сучасні тренди. Це стосується всіх його видів і не в останню чергу - гастрономічного туризму.

Потенціал харчової продукції, особливостей ії сировини, технологій, наявність місцевих харчових брендів, їх умілий брендинг не можна недооцінювати і не бачити в ньому дієвого чинника фоормування туристичної привабливості регіону, а відтак і його успішного економічного розвитку. 
Це обов'язково стосується і послуг харчування в туризмі, які в якості відчутного чинника конкурентноспроможності покликані, на нашу думку, як адаптовуватися до запитів, так і популяризовувати, урізноманітнювати, чи формувати нові вподобання споживачів.

В Україні, як і в багатьох країнах $€ C, \epsilon$ достатньо продуктів, які придатні для реєстрації географрічних зазначень, а з розвитком цього механізму відкриваються нові можливості, нові туристичні пропозиції. Тут фрахівці відзначають потенціал гастрономічного туризму, де в Україні сьогодні можливо розвивати кілька напрямків - винний, сирний чи медовий.

У 2019 році було визначено для реєстрації географрічного зазначення перші 10 українських продуктів із захищеними назвами. Це: сир - захищена назва походження «Гуцульська овеча бриндзя»; кавун - захищена назва походження «Херсонський кавун»; черешня захищена назва походження «Мелітопольська черешня»; мед - захищене географрічне зазначення «Карпатський мед»; вино - захищена назва походження «Шабський»; вино - захищена назва походження «Ялпуг»; вино - захищене геограсрічне зазначення «Закарпаття»; вино - захищене географрічне зазначення «Білгород-Дністровський».

Сир «Гучульська овеча бриндзя» став першим українським товаром, який отримав свідоцтво про реєстрацію географрічного зазначення. Його видало Міністерство розвитку економіки, торгівлі та сільського розвитку України 11 листопада 2019 року. «Гуцульська овеча бриндзя» - це перше українське географрічне зазначення, що відповідає всім європейським вимогам до реєстрації і має право на визнання в ЄС.

Акцент на автентичність, екологічність, унікальність геограсрічного зазначення «Гучульська овеча бриндзя», його правова захищеність повинні вигідно виокремити цей продукт, засвідчити відмінність від схожих аналогів,а влучний інформаційний фоон, що супроводжує брендинг та позиціонування продукту на ринку (а це - історичні традиції, досвід вівчарства на високогір'ї Карпат, унікальна технологія та властивості овечого молока тощо) зумовить додаткові прибутки, доповнить яскравий карпатський колорит автентичним харчовим продуктом 3 давньою історією, що завжди приваблювало туристів.

В Україні віднедавна почали впроваджувати практику еногастрономічних маршрутів як потенціалу просування вітчизняних товарних брендів, а водночас і ефективну складову розвитку туристичної індустрії. Створено проект «Дороги вина та смаку Української Бессарабії», що сприяє формуванню іміджу України як виноробної країни та водночас підвищує попит на місцеву продукцію, в тім числі і серед туристів. Адже під концепцією вищезгаданого організованого еногастрономічного маршруту об'єдналися декілька підприємців і не тільки виноробів, але й виробників продукції вівчарства (баранини і сиру), волоських горіхів та інших, переважно традиційних продуктів.

За словами фрахівців «Одним із перспективних напрямів розвитку ринку туристичних послуг $є$ еногастрономічний туризм, який включає винний та гастрономічний» [4, с. 109]. Розвиток еногастрономічного туризму в Україні слід розглядати на сучасному етапі як сполучну ланкою між виробництвом на місцевому рівні та сорерою послуг, що призведе до створення якісно нового туристичного продукту та сприятиме сталому розвитку місцевих спільнот (підтримці малого та середнього бізнесу, збереженню та подальшому розвитку культурних традицій регіону) [4, с. 118].

Винороби Закарпаття також володіють всіма необхідними ресурсами - територіальними, кліматичними, історичними, економічними щоби долучитися до розвитку високоорганізованого еногастрономічного туризму, запровадженню еногастрономічних маршрутів, які покликані розвивати територію та просувати цей світовий бренд в Україні.

За прогнозами керівника проекту Європейської комісії «Підтримка розвитку системи геограсрічних зазначень в Україні» Саверіо Савіо: «Туристичний еногастрономічний маршрут «Дорога вина та смаку» має впровадити в Україні інноваційний досвід Євросоюзу і сприяти розвитку сільських територій» [5]. До слова цей проект започаткував працю над створенням сирного маршруту довкола географрічних зазначень гуцульської овечої та коров'ячої бриндзі.

Висновки 3 даного дослідження і перспективи подальших розвідок у цьому напрямі. Вищезазначені процеси, глибоке та вдумливе вивчення сучасних світових трендів розвитку гастрономічного туризму, оперативна апробація його інновацій надасть реальні можливості розбудови вітчизняної індустрії туризму, а водночас посприяє підвищенню рівня гастрономічної обізнаності споживачів, популяризуватиме серед них традиційні національні продукти, їх технологію і культуру споживання, що в кінцевому результаті привабить додаткові туристичні потоки, працюватиме на імідж як країни в цілому, так і окремих її регіонів. 


\section{СПИСОК ВИКОРИСТАНИХ ДЖЕРЕЛ:}

1. Корнілова В.В., Корнілова Н.В. Сучасні тенденції розвитку гастрономічного туризму. Ефективна економіка. 2018. № 2. URL: http://www.economy.nayka.com.ua/?op=1\&z=6112

2. Криволапчук В., Филь С. Правова охорона географрічних зазначень у контексті угоди про асоціацію між Україною та ЄС. Теорія і практика інтелектуальної власності. 2018. № 3.

3. Ходаківський Є.І., Якобчук В.П., Литвинчук І.Л. Інтелектуальна власність: економіко-правові аспекти : навч. посіб. Київ : Центр учбової літератури, 2017. 504 с.

4. Мотузенко О.О., Липова М.О. Еногастрономічний туризм як засіб підтримки національного виробника на прикладі Одеської області. Географрія та туризм. 2013. № 24. С. 108-119.

5. 5.Саверіо Савіо: географрічні зазначення відкриють в Україні нову туристичну пропозицію. URL: https://zruchno.travel/News/New/4577?lang=ua

6. Расулова А.М. Потенціал ресторанного бізнесу у розвитку гастрономічного туризму України. Економіка та держава. 2015. № 5. С. 78-83.

7. Про виконання Угоди про асоціацію між Україною, з однієї сторони, та Європейським Союзом, Європейським співтовариством з атомної енергії і їхніми державами-членами, з іншої сторони : Постанова Кабінету Міністрів України від 25.11.2017 р. № 1106. Офріційний вісник України. 2018. № 24. Ст. 852.

8. Вдовічен А.А., Зінченко В.А. Основні фрактори впливу на інноваційний розвиток туристичного бізнесу в Україні. Вісник Чернівецького торговельно-економічного інституту. Економічні науки. 2018. № 1-2. С. 31-39.

9. Гулич О.І. Перспективи України та її регіонів у реалізації соціогуманістичної парадигми розвитку туристично-рекреаційного сектору економіки. Регіональна економіка. 2014. № 3. С. 76-85.

10. Угода про торговельні аспекти прав інтелектуальної власності. URL: https://zakon.rada.gov.ua/laws/ show/981_018 (дата звернення: 02.03.2020).

\section{REFERENCES:}

1. Kornilova V.V., Kornilova N.V. (2018). Suchasni tendentsii rozvytku hastronomichnoho turyzmu [The modern trends of gastronomic tourism development]. Efektyvna ekonomika - Efficient economy, no. 2. Retrieved from: http://www.economy.nayka.com.ua/?op=1\&z=6112 (in Ukrainian)

2. Kryvolapchuk V., Fyl I. (2018). Pravova okhorona heohrafichnykh zaznachen u konteksti uhody pro asotsiatsiiu mizh Ukrainoiu ta YeS [Legal protection of geographical indications in the context of the Association Agreement between Ukraine and the EU]. Teoriia i praktyka intelektualnoi vlasnosti, no. 3. (in Ukrainian)

3. Khodakivskyi Ye.I., Yakobchuk V.P., Lytvynchuk I.L. (2017). Intelektualna vlasnist: ekonomiko-pravovi aspekty: pidruchnyk [Intellectual Property: economic and legal aspects]. Kyiv: Tsentr uchbovoi literatury, 504 p. (in Ukrainian)

4. Motuzenko, O.O., and Lypova M.O. (2013). Enohastronomichnyi turyzm yak zasib pidtrymky natsionalnoho vyrobnyka na prykladi Odeskoi oblasti [Winegastronomic tourism as a means to support national manufacturer by the example of the Odessa region]. Heohrafiia ta turyzm - Geography and tourism, no. 24, pp. 108-119. (in Ukrainian)

5. Saverio Savio: heohrafichni zaznachennia vidkryiut v Ukraini novu turystychnu propozytsiiu. Retrieved from: https://zruchno.travel/News/New/4577?lang=ua

Rasulova A.M. (2015). Potentsial restorannoho biznesu u rozvytku hastronomichnoho turyzmu Ukrainy [Restaurant business potential in the development of Ukrainian gastronomic tourism]. Ekonomika ta derzhava Economy and state, no. 5, pp. 78-83. (in Ukrainian)

6. Pro vykonannia Uhody pro asotsiatsiiu mizh Ukrainoiu, z odniiei storony, ta Yevropeiskym Soiuzom, Yevropeiskym spivtovarystvom z atomnoi enerhii i yikhnimy derzhavamy-chlenamy, $z$ inshoi storony: Postanova Kabinetu Ministriv Ukrainy vid 25.11.2017 r. № 1106. Ofitsiinyi visnyk Ukrainy, 2018, no. 24, st. 852. (in Ukrainian)

7. Vdovichen, A.A., and Zinchenko V.A. (2018). Osnovni faktory vplyvu na innovatsiinyi rozvytok turystychnoho biznesu v Ukraini [Main factors of influences upon innovative development of tourism business in Ukraine]. Visnyk Chernivetskoho torhovelno-ekonomichnoho instytutu. Ekonomichni nauky - Bulletin of the Chernivtsi Trade and Economic Institute. Economic sciences, no. 1-2, pp. 31-39. (in Ukrainian)

8. Hulych O.I. (2014). Perspektyvy Ukrainy ta yii rehioniv u realizatsii sotsiohumanistychnoi paradyhmy rozvytku turystychno-rekreatsiinoho sektoru ekonomiky [Prospects of Ukraine and its regions in the implementation of socio-humanistic paradigm of development of tourist and recreational sector of economy]. Rehionalna ekonomika Regional economy, no. 3, pp. 76-85. (in Ukrainian)

9. Uhoda pro torhovelni aspekty prav intelektualnoi vlasnosti [Agreement on Trade-Related Aspects of Intellectual Property Rights]. Retrieved from: https://zakon.rada.gov.ua/laws/show/981_018 (in Ukrainian) 